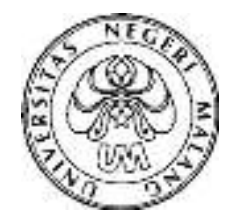

JINOTEP Vol 7 (2) (2020): 76-85

DOI: $10.17977 /$ um031v7i22020p076

JINOTEP (Jurnal Inovasi Teknologi Pembelajaran)

Kajian dan Riset Dalam Teknologi Pembelajaran

http://journal2.um.ac.id/index.php/jinotep/index

\title{
PENGEMBANGAN VIDEO PEMBELAJARAN BAHASA ISYARAT INDONESIA (BISINDO) UNTUK SISWA TUNARUNGU DI SEKOLAH DASAR LUAR BIASA
}

\author{
Sulung Yanuar Anugerah, Saida Ulfa, Arafah Husna \\ Jurusan Teknologi Pendidikan, Fakultas Ilmu Pendidikan, Universitas Negeri Malang \\ Jl. Semarang 5 Malang 65145-0341-575700
}

\section{Article History}

Received: 18-06-2019

Accepted: 21-10-2019

Published: 1-10-2020

\section{Keywords}

Pengembangan Video; Tunarungu; Bahasa Isyarat Indonesia

\begin{abstract}
Abstrak
Pengembangan video pembelajaran ini menggunakan metode penelitian dan pengembangan. Hasil dari pengembangan video pembelajaran ini adalah sebuah video pembelajaran BISINDO.Tujuan pembelajaran BISINDO pada SLB sama seperti sekolah umum begitu juga dengan ruang lingkup materi yang dipelajari. Perbedaannya hanya pada sub bab materi SLB yang lebih sederhana dibandingkan dengan sekolah umum. Mengingat latar belakang SLB adalah anak berkebutuhan khusus, dalam proses pembelajarannya memerlukan bantuan karena adanya keterbatasan yang dimilikinya. Tujuan dari penelitian ini adalah untuk Menghasilkan,mengetahui kelayakan dan respon siswa terhadap video pembelajaran bisindo. Hasil pengujian menunjukkan video pembelajaran sudah berjalan sesuai dengan rancangan awal yang telah dibuat dan direncanakan.
\end{abstract}

\begin{abstract}
The development of this learning video uses research and development methods. The result of the development of this learning video is a BISINDO learning video. The objectives of BISINDO learning at SLB are the same as public schools as well as the scope of the material being studied. The difference is only in the sub-chapter of the SLB material that is simpler compared to public schools. Given that the SLB background is children with special needs, in the learning process they need help because of their limitations. The purpose of this study is to produce, find out the feasibility and response of students to the Bisindo learning video. The test results show the learning video has been running in accordance with the initial design that has been made and planned by the author.
\end{abstract}

Corresponding author :

Adress: Jalan Raya Apel Semanding Sumber Sekar Kec.Dau

Kab.Malang.

Instansi: Teknologi Pendidikan, Universitas Negeri Malang

E-Mail: Sulungyanuar0@gmail.com
2020 Universitas Negeri Malang p-ISSN 2406-8780 e-ISSN 2654-7953 


\section{PENDAHULUAN}

Pendidikan nasional yang berfungsi untuk mengembangkan kemampuan dan membentuk watak peserta didik serta membentuk peradaban bangsa yang bermartabat dalam rangka mencerdaskan kehidupan bangsa yang berlaku di masyarakat yang bertujuan untuk mengembangkan potensi pembelajar, yang diwujudkan dalam bentuk pendidikan sekolah.

Program pendidikan di sekolah umum memungkinkan dinikmati bagi anak-anak yang dapat dikategorikan sebagai normal. Namun, pendidikan di sekolah umum seperti sekolah dasar/SD, sekolah menengah pertama/SMP dan sekolah menengah atas/SMA seringkali tidak memungkinkan bagi anak yang memiliki keadaan khusus atau siswa luar biasa (Wasita, 2012). Siswa dengan keadaan khusus dapat disebut dengan anak berkebutuhan khusus yang tentunya mempunyai kebutuhan dan pelayanan yang berbeda dari anak pada umumnya.

Tujuan pendidikan khusus bagi siswa tunarungu yaitupengembangkan kecakapan dasar dan memiliki pengetahuan dasar untuk bekal hidup sehari-hari (Purwoko \& Masitoh, 2018).

Anak berkebutuhan khusus adalah anakanak yang mengalami penyimpangan, kelainan atau ketunaan dalam segi fisik, mental, emosi, dan sosial, atau gabungan dari hal-hal tersebut sehingga mereka memerlukan pendidikan dengan pelayanan yang spesifik dan berbeda dengan anak pada umumnya sesuai dengan bentuk kebutuhannya.

Gangguan pada pendengaran anak tunarungu berdampak luas baik dalam aspek akademis maupun penyesuaian sosial dan emosional (Effendy, Sihkabuden, \& Husna, 2019; Zakia, Sunardi, \& Yamtinah, 2016). Anak tunarungu mengalami kesulitan dalam menyampaikan pikiran, pendapat, kebutuhan dan keinginannya kepada orang lain. Akibatnya, ia sulit dipahami maupun memahami orang lain dan merasa terisolasi dari lingkungan sosial. Selain itu, anak tunarungu seringkali melampiaskan frustasi dalam bentuk tindakan fisik maupun tempertantrum karena tidak dapat mengungkapkannya secara verbal. Secara akademis, anak tunarungu mengalami ketertinggalan karena hambatan dalam bahasa yang merupakan aspek penting dalam proses akademis.

Tunarungu merupakan istilah yang digunakan untuk menunjukkan keadaan kehilangan pendengaran yang dialami oleh seseorang. Secara umum tunarungu dikategorikan kurang dengar dan tuli, sebagaimana yang diungkap (Anggraeni, Sarinastiti, \& Wati, 2019; Anggraeni et al., 2019; Rofiandaru, 2013) bahwa Tunarungu adalah suatu istilah umum yang menunjukkan kesulitan mendengar yang meliputi keseluruhan kesulitan mendengar dari yang ringan sampai yang berat, digolongkan ke dalam tuli dan kurang dengar.

Kehilangan pendengaran bagi seseorang sama halnya kehilangan sesuatu yang sangat penting dalam kehidupannya. Menurut (Wasita, 2012) anak tunarungu mengalami kesulitan dalam berbahasa karena mereka tidak mendengar sehingga bahasanya tidak dapat berkembang dengan baik yang mengakibatkan masalah pada saat berkomunikasi. Anak tunarungu dapat dikatakan memiliki potensi untuk berbicara, namun akibat dari gangguan pada indra pendengarannya, maka anak tidak mampu mendengarkan bunyi atau suara dengan baik seperti anak normal pada umumnya (Mudjiyanto, 2018). Ketidakmampuan yang dialami anak tunarungu menjadikan anak tidak mampu untuk melakukan eksplorasi dan memproduksi bunyi/suara yang ada di lingkungannya.

Menurut Undang-undang Dasar 1945 Pasal 31 Ayat 1 yang artinya tanpa terkecuali setiap warga negara berhak mendapatkan pendidikan, termasuk anak dengan penyandang berkebutuhan khusus (UUD, 1945).

Bahasa Isyarat (BISINDO dan SIBI) Sebagai Media Pengenalan Huruf Dan Angka Bagi Penderita Tunarungu dan Wicara, diharapkan dapat membantu para pendidik sebagai media ajar dalam proses pembelajaran bahasa isyarat untuk memperkenalkan huruf dan angka kepada siswa tunarungu wicara khususnya kelas satu di Sekolah Luar Biasa (Kautsar, Borman, \& Sulistyawati, 2015; Pratama, Rakun, \& Hardianto, 2019). 
78 JINOTEP (Jurnal Inovasi dan Teknologi Pembelajaran) Kajian dan Riset dalam Teknologi Pembelajaran Vol.7, No.2, Oktober 2020, Hal.76-85

Pendidikan untuk anak berkebutuhan khusus adalah pendidikan yang sesuai dengan kebutuhan masing-masing anak yang menyandang kekhususan. Pendidikan yang tidak sesuai dengan karakteristik dan kebutuhan siswa tersebut tidak dapat menghasilkan sumber daya manusia yang berkualitas. Hasil yang diharapkan dari pendidikan ini sama seperti hasil pendidikan pada pendidikan umum hanya saja bentuk pelayanannya yang membedakan sekolah umum dan sekolah kebutuhan khusus.

Salah satu anak yang membutuhkan pendidikan khusus dan bersekolah di sekolah luar biasa yaitu anak yang memiliki ketunaan atau kekurangan pada alat indera pendengarannya, yang biasa disebut dengan tunarungu. Meskipun sebenarnya IQ mereka sama seperti anak normal, namun karena pengaruh keterbatasan pendengaran tersebut juga mempengaruhi mental, sosial, maupun intelektual mereka sehingga menyebabkan pengetahuan yang mereka peroleh hanya sebagian saja.

Secara sederhana, multimedia yang diartikan sebagai "lebih dari satu media yang bermanfaat". Multimedia bisa berupa kombinasi antara teks, grafik, animasi, suara, dan gambar. Namun pada bagian ini perpaduan dan kombinasi dua atau lebih jenis media ditekankan kepada kendali komputer sebagai penggerak keseluruhan gabungan media ini dan manusia sebagai agent of change. Dengan demikian arti multimedia yang umumnya dikenal dewasa ini adalah berbagai macam kombinasi grafik, teks, suara, video, dan animasi. Penggabungan ini merupakan suatu kesatuan yang secara bersamasama menampilkan informasi, pesan, atau isi pelajaran (Amaliyah, Irwansyah, Windayani, \& Ramdhani, 2018; Mayer, 2002; Mufdalifah, 2017; Surjono, 2017).

Media sebagai segala sesuatu yang dapat digunakan di sekolah maupun pembelajaran luar sekolah untuk menyalurkan pesan dari pengirim pesan kepada penerima pesan, sehingga dapat memotivasi pikiran, perasaan, perhatian, dan minat peserta didik, sehingga dapat membuat proses belajar mengajar berlangsung dengan efektif dan efisien, serta tercapainya sebuah tujuan pembelajaran.
Tujuan pembelajaran BISINDO pada SLB (Sekolah Luar Biasa) sama seperti sekolah umum begitu juga dengan ruang lingkup materi yang dipelajari (Prasetya, 2016; Purwoko \& Masitoh, 2018; Setyawan, 2015). Perbedaannya hanya pada sub bab materi SLB yang lebih sederhana dibandingkan dengan sekolah umum. Mengingat latar belakang SLB adalah anak berkebutuhan khusus, dalam proses pembelajarannya memerlukan bantuan karena adanya keterbatasan yang dimilikinya. Terutama anak tunarungu yang memiliki keterbatasan dalam komunikasi dan pendengarannya, sehingga menyebabkan anak tunarungu memiliki tipe belajar tersendiri.

Permasalahan umum bagi yang dihadapi oleh pembelajar tunarungu saat ini adalah kurang dapat memahami hal yang bersifat abstrak dan verbal, padahal kemampuan verbal sangat diutamakan dalam proses belajar mengajar disekolah maupun diluar sekolah dalam hal ini bisa diartikan keluarga dan masyarakat. Oleh sebab itu, guru kelasnya memerlukan alat bantu berupa media yang berbentuk video pembelajaran bisindo agar siswa tunarungu dapat menerima isi dari materi pembelajaran melalui indera mata (Somantri, 2012).

Wina Sanjaya dalam (Prasetya, 2016) berpendapat, Agar proses pembelajaran berjalan lancar dan baik, pendidik dalam mengajar mustahil tidak menggunakan media atau alat bantu mengajar. Pendidik harus menggunakan media dalam mengajar entah itu buku acuan atau apa saja yang bisa membantu dalam proses pembelajaran agar peserta didik paham. Sebab dengan menggunakan media pembelajaran proses pembelajaran jadi lebih menarik dan peserta didik lebih memahami apa yang disampaikan oleh pendidik.

Berdasarkan hasil wawancara yang dilakukan terhadap guru kelas IV tunarungu SDLBN Kedungkandang 4 Kota Malang, diperoleh bahwa guru kekurangan media pembelajaran BISINDO. Dalam proses pembelajaran, untuk menjelaskan hal yang abstrak guru menggambar manual di papan tulis agar siswa dapat menerima yang disampaikan oleh guru. 
Siswa tunarungu yang mempunyai kekurangan pada indera pendengarannya hanya dapat memanfaatkan indera-indera lain yang mereka punya seperti indera penglihatan dan perasa (Arnez, 2016). Oleh sebab itu, salah satu upaya yang dapat diusahakan oleh guru yaitu menggunakan sebuah media pembelajaran bersifat video. Media video pembelajaran ini berfungsi menyalurkan pesan dari sumber kepada penerima pesan.

Video pembelajaran merupakan salah satu bentuk dari media pembelajaran berupa video yang didalamnya juga memuat kata atau kalimat keterangan untuk mengembangkan daya ingat siswa terhadap materi. Video pembelajaran bisindo dapat dikembangkan sebagai media pembelajaran pada siswa tunarungu karena siswa dapat memanfaatkan indera penglihatannya dalam memahami pesan materi yang ada pada media video pembelajaran tersebut (Hapsari, Toenlioe, \& Soepriyanto, 2019; Putri, Parmiti, \& Sudarma, 2020). Selain itu, siswa juga dapat mendapatkan perasaan senang yang ditimbulkan dari permainan yang dilakukan.

Penggunaan media gambar berbentuk video pembelajaran dapat membantu siswa dalam mengenal bentuk benda melalui bentuk gambar dan melatih siswa untuk dapat menganalisis dan menyimpulkan sehingga siswa dapat memahami materi yang disampaikan.

Penelitian ini mempunyai keunggulan yaitu belum adanya media pembelajaran berupa video pembelajaran untuk mata pelajaran BISINDO bagi siswa SDLBN. Nilai unggulan pengembangan media pembelajaran video pembelajaran yang dilakukan peneliti dibandingkan dengan penelitian sebelumnya adalah pada panduan pemakaian media pembelajaran tersebut dalam bentuk RPP (Rancangan Pelaksanaan Pembelajaran) yang dibuat untuk gurunya masing-masing.

\section{METODE}

Model yang digunakan oleh peneliti adalah desain model Borg and Gall (Meredith Damien Gall, Borg, \& Gall, 2003) yaitu model deskriptif yang menggambarkan langkahlangkah prosedur dengan alur yang mesti dilakukan untuk menghasilkan produk baru atau mengembangkan produk yang telah ada sehingga semakin meningkatkan efektivitas dan efisiensi suatu sistem.

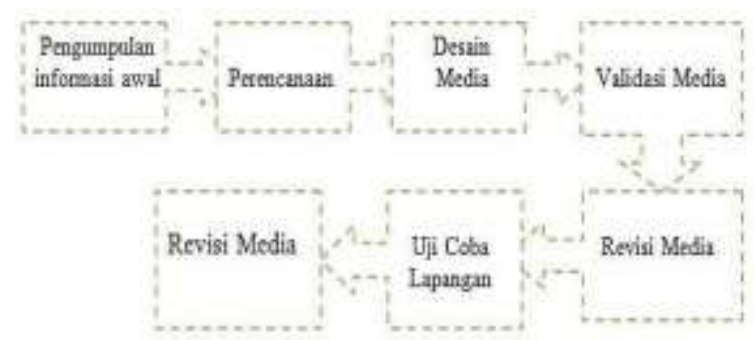

Gambar1: Langkah-langkah penelitian Borg and Gall

Langkah-langkah dalam penelitian pengembangan menurut Borg and Gall, meliputi: (1) Pengumpulan informasi awal, (2) Perencanaan, (3) Desain media, (4) Validasi media, (5) Revisi media, (6) Uji coba lapangan Dan (7). Revisi media tahap 2 (M D Gall, 1989). Media pembelajaran video pembelajaran BISINDO yang akan dikembangkan memiliki spesifikasi sebagai berikut:(1).Didesain dengan menggunakan Adobe after FX.( 2) Mempunyai durasi waktu 8 menit.(3).Digunakan dalam pembelajaran materi BISINDO pada tema 4 subtema 2.

Peneliti akan melakukan pengembangan media pembelajaran video. Pada tahap ini peneliti menentukan kerangka isi materi yang akan disajikan dalam video pembelajaran ini . Kemudian membuat desain video pembelajaran melalui software dari komputer yaitu adobe after effect yang terbaru.

Pada tahap validasi media ini, dilakukan validasi oleh beberapa pakar atau tenaga ahli media, ahli materi dan guru kelas IV tunarungu yang dikembangkan untuk menilai media dan isi dari materi yang akan disampaikan tersebut.

Setiap validator (materi dan media) diminta untuk memberikan penilaian kemudian akan dilakukan analisis data. Sehingga dapat diketahui kekurangan dari produk tersebut. Validator desain media pembelajaran pada pengembangan media pembelajaran video pembelajaran materi BISINDO.

Revisi media pada tahap ini yaitu berupa media pembelajaran video video pembelajaran materi BISINDO yang bertujuan untuk memperbaiki kekurangan yang didapat setelah 
80 JINOTEP (Jurnal Inovasi dan Teknologi Pembelajaran) Kajian dan Riset dalam Teknologi Pembelajaran Vol.7, No.2, Oktober 2020, Hal.76-85

melakukan validasi oleh ahli-ahli pada tahap sebelumnya.

Uji coba media dilakukan setelah melakukan validasi sebanyak dua kali media dan perbaikan atau revisi media untuk mengetahui kelayakan media pembelajaran berupa video pembelajaran BISINDO saat digunakan dalam pembelajaran.

Peneliti menyajikan prosedur dan hasil uji coba produk dilakukan untuk mengetahuhi apakah pengembangan media pembelajaran berupa video pembelajaran BISINDO ini layak digunakan sebagai media pembelajaran di SDLBN, kemudian siswa diharapkan mencoba mempelajari media pembelajaran berupa video pembelajaran BISINDO, selanjutnya peneliti meminta siswa memberikan komentar atau masukan tentang media pembelajaran berupa video pembelajaran BISINDO yang baru saja mereka lihat (Parmawati, Prasetyawati, \& Prianto, 2017).

Revisi pada tahap ini dilakukan, apabila dalam pemakaian kondisi nyata terdapat kekurangan atau kelemahan. Penilaian dilakukan oleh validator media dan validator materi, kemudian dilakukan revisi berdasarkan saran yang diberikan oleh validator media, dan validator materi. Selain itu, respon guru dan siswa menjadi pertimbangan untuk melakukan revisi.

Berdasarkan kegiatan tersebut peneliti akan melakukan pengembangan media pembelajaran yaitu video pembelajaran materi BISINDO yang bersifat video agar dapat membantu guru dan siswa tunarungu dalam pembelajaran BISINDO di kelas.

\section{HASIL}

Hasil yang diperoleh peneliti pada penelitian video pembelajaran BISINDO sebagai media pembelajaran video yang dapat dimanfaatkan pada anak tunarungu. Penggunaan video pembelajaran BISINDO sebagai media pembelajaran dapat memperjelas bahan pembelajaran dengan sajian materi yang ringkas dan disesuaikan dengan kebutuhan siswa tunarungu serta dapat digunakan dengan mudah dan praktis untuk dibawa kemana saja. Berikut adalah data hasil dari penelitian yang dilakukan oleh peneliti.

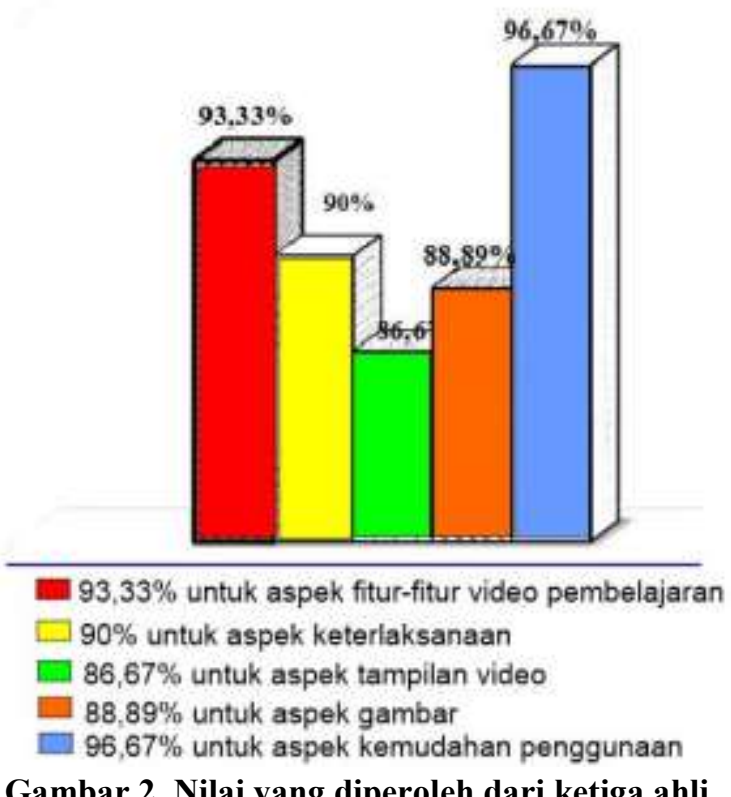

Gambar 2 menunjukan nilai yang diperoleh dari ketiga ahli materi dan dapat dilihat persentase skor kelayakan dari setiap aspek pada media pembelajaran video pembelajaran BISINDO dengan menggunakan rumus skala likert dengan hasil penilaian $89,33 \%$ untuk aspek kualitas isi flash card, 83,33\% untuk aspek kebahasaan materi, $84 \%$ untuk aspek keterlaksanaan isi sajian materi flash card, dan $90 \%$ untuk aspek tampilan video (video isi sajian materi). Sehingga diperoleh rata-rata penilaian untuk seluruh aspek pada media pembelajaran video pembelajaran BISINDO yaitu $86,78 \%$. Dengan demikian validasi pada ahli materi mendapatkan kategori sangat sesuai. Berikut dalam gambar peneliti sajikan data hasil ahli materi dari masing-masing aspek penilaian dalam bentuk grafik.

Gambar 3 merupakan nilai yang diperoleh dari validasi guru BISINDO SDLB Negeri, dengan hasil penilaian $90 \%$ untuk aspek kualitas isi, 95,56\% utuk tampilan media, dan 95\% untuk aspek kualitas teknis. Sehingga diperoleh rata-rata penilaian untuk seluruh aspek pada media pembelajaran video pembelajaran BISINDO adalah 93,52\% dengan kategori sangat baik. hasil penilaian oleh guru terhadap media pembelajaran video 
pembelajaran BISINDO disajikan juga data dalam bentuk grafik hasil penilaian oleh ahli materi dari masing-masing aspek penilaian.

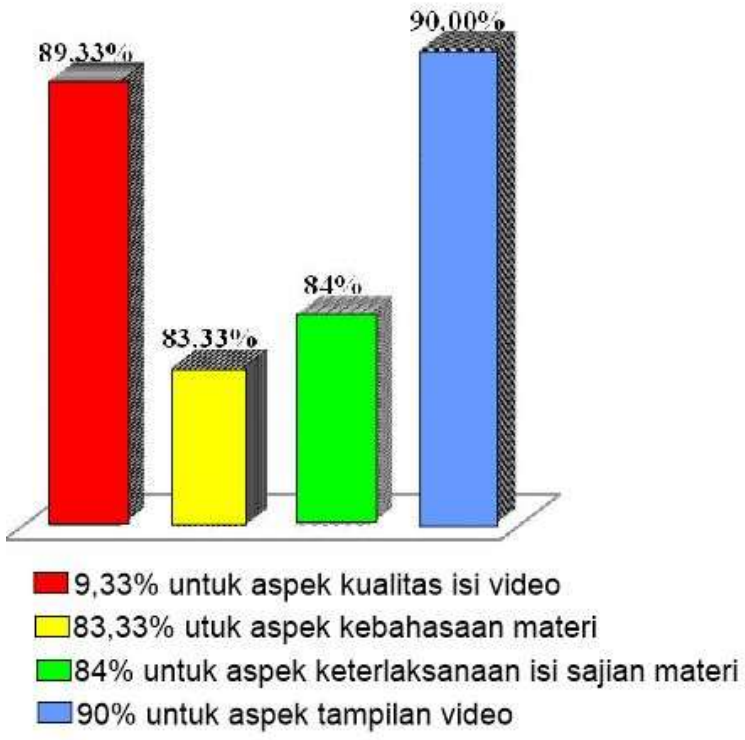

Gambar 3. Nilai yang diperoleh dari validasi guru

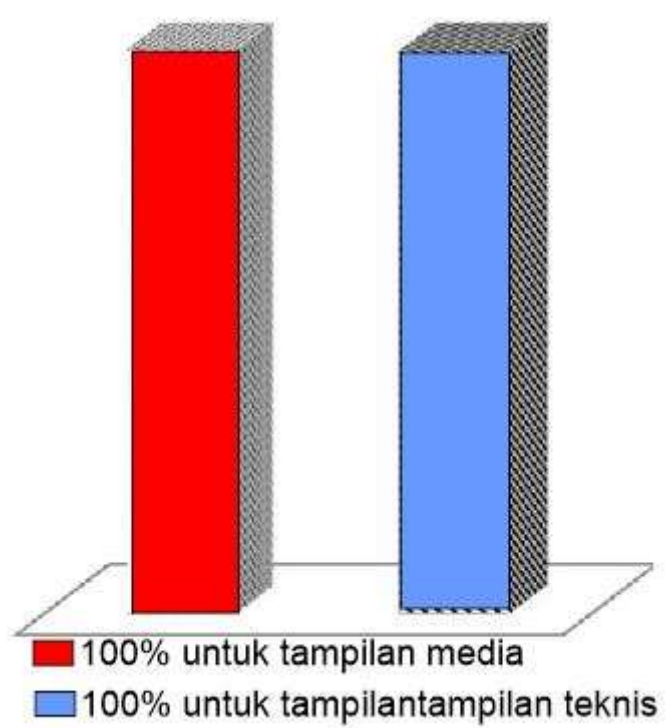

Gambar 4. Penilaian uji coba di sekolah

Gambar 4 menunjukan penilaian uji coba disekolah. Sama halnya dengan uji kelompok kecil, uji lapangan juga terdapat tiga aspek yang diukur. Dari ketiga aspek tersebut semuanya mendapatkan persentase penilaian $100 \%$, artinya siswa merespon positif media video pembelajaran BISINDO. Selain dalam bentuk tabel hasil penilaian uji coba lapangan disajikan juga data dalam bentuk grafik. Berikut merupakan data gambar hasil penilaian uji coba lapangan dari masing-masing aspek penilaian.

\section{PEMBAHASAN}

Berdasarkan hasil penelitian, maka peneliti akan membahas hasil penelitian tersebut yang didasarkan teori literatur yang ada dan relevan. Pada tahapan awal yaitu mengumpulkan informasi untuk menganalisis kebutuhan objek penelitian yaitu siswa tunarungu.

Pengumpulan informasi awal dilakukan dengan wawancara kepada guru kelas dalam hal ini guru kelas SDLBN 4 Kedungkandang Kota Malang dan kajian literatur terhadap karakteristik obyek penelitian dan solusi untuk menangani permasalahan yang ditemukan. Diketahui bahwa anak tunarungu, menjadikan penglihatan sebagai indera pokok. Dengan demikian, guru dituntut untuk memberikan materi pembelajaran dengan menggunakan alat bantu video untuk membantu kegiatan pembelajaran dikarenakan siswa tunarungu sulit memahami hal-hal yang bersifat abstrak. Dengan demikian, dengan kajian literatur yang dilakukan peneliti mengembangkan kartu belajar berupa video pembelajaran BISINDO. Video pembelajaran termasuk media

Video yang berupa kartu bergambar yang berhubungan dengan materi pelajaran, sehingga dapat menyalurkan informasi pembelajaran. Video pembelajaran dirancang dengan menyusun rancangan materi yang akan dibuat sesuai dengan kompetensi dasar dan indikator-indikator yang akan dicapai dalam pembelajaran. Selanjutnya peneliti membuat desain untuk halaman awal atau judul, serta mencari dan mengumpulkan gambar-gambar dari berbagai sumber, kemudian membuat dan menggabungkan menjadi satu-kesatuan sesuai dengan fitur video pembelajaran dengan menggunakan software Adobe after fx.

Desain tersebut diharapkan dapat menjadi dasar dalam mengembangkan media pembelajaran video pembelajaran BISINDO. Video pembelajaran disajikan dengan desain tampilan yang menarik, sehingga dapat memberi ketertarikan siswa untuk belajar diharapkan menjadi media pembelajaran yang dapat digunakan guru maupun siswa untuk membantu dalam kegiatan pembelajaran. 
82 JINOTEP (Jurnal Inovasi dan Teknologi Pembelajaran) Kajian dan Riset dalam Teknologi Pembelajaran Vol.7, No.2, Oktober 2020, Hal.76-85

Media video pembelajaran BISINDO dinyatakan sangat layak oleh validator ahli media dengan skor penilaian dalam persen $92,41 \%$. Skor tersebut menunjukan bahwa Video pembelajaran yang dikembangkan dinilai dapat menarik siswa tunarungu untuk membaca karena penyajiannya yang didukung dengan ilustrasi gambar dan kontras warna yang menarik, serta video pembelajaran yang bersifat video dinilai dapat membantu siswa tunarungu memahami materi yang disampaikan. Hal tersebut sesuai dengan manfaat dari adanya media pembelajaran yaitu mampu meningkatkan dan mengarahkan perhatian siswa sehingga dapat menimbulkan motivasi belajar siswa dan mampu menanggulangi keterbatasan indera, ruang dan waktu.

Sajian materi video pembelajaran juga mendapatkan kategori sangat sesuai oleh para ahli materi dengan rata-rata persentase skor $86,35 \%$. Hal tersebut berarti materi yang disajikan dalam video pembelajaran sesuai dengan indikator yang akan dicapai dalam pembelajaran serta gambar yang disukai dalam video pembelajaran sesuai dengan materi yang akan disampaikan sehingga mudah dipahami siswa. Video pembelajaran menggunakan ilustrasi gambar yang tepat dalam menyampaikan materi yang disajikan sehingga materi tersebut dapat sampai kepada siswa. Materi pada media pembelajaran dikatakan sesuai jika dalam penyajian gambar dalam media pembelajaran mudah dipahami dan dapat merangsang pemahaman akan materi.

Media video pembelajaran menurut guru kelas tunarungu sudah sangat baik dengan rata-rata persentase skor $92,78 \%$. Hal ini berarti media pembelajaran sangat baik untuk diteruskan pada uji coba siswa. Validator guru menilai produk video pembelajaran sudah sangat sesuai dengan kebutuhan siswa tunarungu karena mengandung gambar-gambar video yang membuat siswa memahami hal-hal yang terlalu abstrak yang kurang dimengerti oleh siswa tunarungu dan menggunakan warna-warna yang menarik dengan fungsi memikat perhatian siswa.

Penilaian dari guru kelas tunarungu memperoleh persentase paling tinggi dibandingkan dengan validasi dari ahli media dan ahli materi. Hal tersebut disebabkan, video pembelajaran BISINDO dianggap sebagai media pembelajaran yang inovatif, kreatif, dan termasuk media yang dibutuhkan untuk membantu pembelajaran siswa,terutama oleh siswa dengan penyandang ketunaan pada sistem pendengarannya, karena video pembelajaran merupakan media video yang disesuaikan dengan kebutuhan siswa tunarungu.

Manusia diciptakan dengan kelebihan dan kekurangan masing-masing. Tunarungu adalah penyandang cacat fisik yang memiliki keterbatasan pada pendengaran. Tunarungu merupakan istilah yang digunakan untuk menunjukan keadaan seseorang yang kekurangan kehilangan pendengaran yang dialami oleh seseorang. Secara umum tunarungu dikategorikan kurang dengar dan tuli, sebagaimana yang diungkap oleh (Wasita, 2012) bahwa tunarungu adalah suatu istilah umum yang menunjukan kesulitan mendengar yang meliputi seluruh kesulitan mendengar dari yang ringan sampai kelas berat, digolongkan kedalam tuli dan kurang dengar kelasnya.

Pengertian mengenai tunarungu juga sangat beragam dalam dunia ini, yang semuanya mengacu pada keadaan atau kondisi pendengaran anak tunarungu. Tunarungu dapat diartikan sebagai suatu keadaan kehilangan atau berkurangnya pendengaran yang mengakibatkan seseorang dari usia berapapun tidak dapat menangkap berbagai rangsangan terutama melalui pendengaran (Mudjiyanto, 2018).

Masalah utama pada anak dengan gangguan pendengaran adalah masalah komunikasi itu adalah faktanya. Penderitaan anak tunarungu saat ini ialah berpangkal dari kesulitan mendengar, sehingga seorang tunarungu pembentukan bahasa sebagai salah satu cara berkomunikasi menjadi terhambat dan sulit, sehingga perlu adanya bahasa isyarat (Kautsar et al., 2015; Yuniati, 2013).

Ketidakmampuan berbahasa pada anak tunarungu khususnya secara herbal, akan mengalami banyak kesulitan dalam menyampaikan pikiran, perasaan, gagasan, kebutuhan, saran khusus dan hendaknya pada orang lain, sehingga kebutuhan mereka kurang terpuaskan secara sempurna. Di samping itu juga 
tidak dimengerti oleh orang lain, anak tuna rungu sukar memahami orang lain,sehingga tidak jarang mereka terkucil atau terisolasi dari lingkungan sosialnya.dan ada juga yang bisa berbaur dengan masyarakat saat ini dengan asian para game (Pradana \& Ikom, 2015).

Saluran komunikasi berhubungan dengan panca indera, yaitu pengelihatan, pendengaran, peraba, penciuman, dan perasa. Dengan demikian, panca indera sebagai saluran komunikasi berpengaruh terhadap efektif tidaknya pros komunikasi. Jika salah satu dari saluran tersebut terganggu, dapat dipastikan terganggu pula proses komunikasi. Untuk itu, seseorang yang kehilangan fungsi alat indera pendengarannya atau yang biasa dikenal dengan sebutan tunarungu akan mengalami hambatan yang lebih besar dalam proses komunikasi verbal.

Anak Berkebutuhan Khusus (ABK) merupakan istilah lain menggantikan kata yang artinya sama yaitu "Anak Luar Biasa (ALB)" yang menandakan adanya kelainan khusus dan kekurangan pada indranya. Anak berkebutuhan khusus mempunyai karakteristik yang berbeda sangat antara satu dengan yang lainnya. Di negara indonesia, siswa berkebutuhan khusus yang mempunyai gangguan perkembangan dan telah diberikan layanan (Kautsar et al., 2015; Yuniati, 2013) (yuniati,y 2011:30)

Dampak ketunarunguan bagi individu (anak tunarungu itu sendiri) yang memiliki kosa kata yang sedikit sulit, sehingga perlu dimaksimalkan pada indera penglihatannya dalam pembelajaran .

Penelitian pendahuluan dilakukan dengan wawancara oleh guru kelas IV tunarungu tentang pembelajaran materi BISINDO dan media-media yang dibutuhkan. Pada langkah ini dilakukan dengan tujuan untuk mengetahui bagaimana proses pembelajaran dan apa saja media yang dibutuhkan oleh siswa tunarungu agar peneliti dapat merancang produk awal dari Video pembelajaran BISINDO yang akan dikembangkan. Format dari Video pembelajaran disesuaikan dengan kemampuan siswa tunarungu yang kesulitan dalam pembelajaran yang abstrak (Pradana \& Ikom, 2015).

Setelah melakukan penelitian dan pengumpulan informasi awal, selanjutnya perlu perencanaan atau planning. Peneliti merancang sebuah media pembelajaran yang diharapkan dapat membantu proses belajar mengajar melalui berbagai macam sumber seperti buku-buku, internet, dan jurnal-jurnal.

Tunarungu, sama halnya dengan difabel yang lain yang merupakan warga negara Indonesia berhak memperoleh pendidikan secara layak. Seperti diketahui Anak Berkebutuhan Khusus (ABK) membutuhkan perhatian lebih untuk meningkatkan fokus terhadap proses belajar, selain itu peran bahasa isyarat sangat penting (Effendi, Hardiyana, \& Gustiana, 2016).

Kelebihan fungsi indra lainnya perlu dioptimalkan antara lain melalui visualisasi. Ini dapat dibantu dengan multimedia. Multimedia merupakan gabungan dua atau lebih format media yang dapat terdiri dari teks, grafis, foto, animasi, dan video (Hwang, Chen, \& Hsu, 2006; Mayer, 2005).

Tantangan kebutuhan peserta didik berkebutuhan khusus membutuhkan empati dan kesadaran yang tinggi dari para pendidik dan orang tua. Para guru dituntut memiliki kompetensi yang lebih banyak dalam rangka pengembangan media dan sumber belajar yang adaptif terhadap kebutuhan peserta didiknya. Untuk melakukan hal tersebut para pendidik perlu memiliki literasi media dan keterampilan TIK yang memadai (Alfindasari \& Surahman, 2014; Praherdhiono et al., 2019). Banyak hal yang dapat dilakukan salah satunya dengan senang mengikuti pelatihan-pelatihan pengembangan media untuk meningkatkan kompetensinya.

\section{SIMPULAN}

Berdasarkan hasil penelitiian yang telah dilakukan dapat disimpulkan bahwa Media pembelajaran video pembelajaran BISINDO yang menarik dan dirancang untuk anak tunarungu telah berhasil dikembangkan dengan desain untuk membuat dan menggabungkan gambar dan kata sehingga terbentuklah fitur video pembelajaran yang utuh. Berdasarkan hasil uji kelayakan ahli materi, ahli media dan uji coba di kelas diperoleh kesimpulan bahwa media video Bisindo telah valid, layak dan dapat digunakan dalam pembelajaran pada siswa tunarungu. 


\section{DAFTAR PUSTAKA}

Alfindasari, D., \& Surahman, E. (2014). Sumber Daya Manusia dan Pendidikan di Era Global: Sebuah Tinjauan Terhadap Penelitian Teknologi Pendidikan di LPTK. Proceeding Seminar Nasional Teknologi Pembelajaran. Yogyakarta: UNY.

Amaliyah, L., Irwansyah, F. S., Windayani, N., \& Ramdhani, M. A. (2018). Design of Android Interactive Multimedia for the Concept of Aromatic Compound. MATEC Web of Conferences, 197, 16004. EDP Sciences.

Anggraeni, M., Sarinastiti, W., \& Wati, S. (2019). Indonesian Sign Language (SIBI) Vocabulary Learning Media Design Based on Augmented Reality for Hearing-Impaired Children. Jurnal EECCIS, 13(3), 139-144.

Arnez, G. (2016). Efektivitas Teknik Fading dan Prompting untuk Meningkatkan Kosakata Fungsional Anak dengan Gangguan Spektrum Autis di Kelas 1 SDLB Putra Jaya Malang. SKRIPSI Jurusan Pendidikan Luar BiasaFakultas Ilmu Pendidikan UM.

Effendi, D., Hardiyana, B., \& Gustiana, I. (2016). Perancangan Program Aplikasi Pembelajaran Ipa Materi Sistem Pernapasan Berbasis Multimedia Untuk Siswa Sdlb Bagian B Tuna Rungu Menggunakan Object Oriented Approach. Simetris: Jurnal Teknik Mesin, Elektro Dan Ilmu Komputer, 7(2), 605-618.

Effendy, P. A., Sihkabuden, S., \& Husna, A. (2019). Penerapan Kurikulum 2013 di SDLBK Bhakti Luhur Malang pada Kelas B (Tunarungu). Jurnal Kajian Teknologi .... Retrieved from http://journal2.um.ac.id/index.php/jktp/article/ view/4546

Gall, M D. (1989). Gall. JP, \& Borg, WR (2007). Educational Research: An Introduction, 8.

Gall, Meredith Damien, Borg, W. R., \& Gall, J. P. (2003). Educational research: An introduction. Longman Publishing.

Hapsari, N. D., Toenlioe, A. J. E., \& Soepriyanto, Y. (2019). Pengembangan Augmented Reality Video Sebagai Suplemen Pada Modul Bahasa Isyarat. Jurnal Kajian Teknologi Pendidikan, 1(3), 185-194.

Hwang, W.-Y., Chen, N.-S., \& Hsu, R.-L. (2006). Development and evaluation of multimedia whiteboard system for improving mathematical problem solving. Computers \& Education, $46(2)$, 105-121. https://doi.org/10.1016/j.compedu.2004.05.00 5
Kautsar, I., Borman, R. I., \& Sulistyawati, A. (2015). Aplikasi Pembelajaran Bahasa Isyarat Bagi Penyandang Tuna Rungu Berbasis Android Dengan Metode BISINDO. Semnasteknomedia Online, 3(1), 4.

Mayer, R. E. (2002). Multimedia learning. In Psychology of learning and motivation (Vol. 41, pp. 85-139). Elsevier.

Mayer, R. E. (2005). Cognitive theory of multimedia learning. The Cambridge Handbook of Multimedia Learning, 3148.

Mudjiyanto, B. (2018). Pola Komunikasi Siswa Tunarungu di Sekolah Luar Biasa Negeri Bagian B Kota Jayapura. Jurnal Studi Komunikasi Dan Media, 22(2), 151-166.

Mufdalifah, M. (2017). Personalized Learning Dan Multimedia Berbasis Komputer Masih Perlukah Guru. JINOTEP (Jurnal Inovasi Dan Teknologi Pembelajaran) Kajian Dan Riset Dalam Teknologi Pembelajaran, pp. 50-57. https://doi.org/10.17977/um031v1i12014p050

Parmawati, S. B., Prasetyawati, W., \& Prianto, R. M. A. (2017). Efektivitas pendekatan modifikasi perilaku dengan teknik Fading dan token economy dalam meningkatkan kosakata siswa tuna rungu prelingual profound. Psibernetika, $8(1)$.

Pradana, N., \& Ikom, S. (2015). Strategi Komunikasi Antar Anggota Dalam Kelompok Penyandang Tunarungu (Studi Kualitatif Deskriptif Komunikasi Verbal-Nonverbal Antar Pribadi Pada Anggota Tunarungu di Malang). Universitas Brawijaya: Jurusan Komunikasi, Fakultas Ilmu Sosial Dan Ilmu Politik.

Praherdhiono, H., Setyosari, P., Degeng, I. N. S., Slamet, T. I., Surahman, E., Adi, E. P., ... Abidin, Z. (2019). Teori dan Implementasi Teknologi Pendidikan: Era Belajar Abad 21 dan Revolusi Industri 4.0. Seribu Bintang.

Prasetya, Y. T. (2016). Peningkatan Kemampuan Menulis Struktur Kata Melalui Penggunaan Media Teka Teki Silang Bagi Siswa Tunarungu Sekolah Dasar 1 Di SLB BC Bhakti Putera Bahagia Klaten. Widia Ortodidaktika, 5(1), 8392.

Pratama, A. A., Rakun, E., \& Hardianto, D. (2019). Human Skeleton Feature Extraction from 2Dimensional Video of Indonesian Language Sign System (SIBI [Sistem Isyarat Bahasa Indonesia]) Gestures. Proceedings of the 2019 5th International Conference on Computing and Artificial Intelligence, 100-105.

Purwoko, B., \& Masitoh, S. (2018). Permainan TekaTeki Silang Bergambar Terhadap Penguasaan 
Kosakata Siswa Tunarungu. Jurnal Pendidikan Khusus, 10(2).

Putri, N. M. L. K., Parmiti, D. P., \& Sudarma, I. K. (2020). Pengembangan Video Pembelajaran dengan Bahasa Isyarat Berbasis Pendidikan Karakter pada Siswa Kelas V di SDLB-B Negeri I Buleleng Tahun Pelajaran 2017/2018. Jurnal EDUTECH Undiksha, 7(2), 81-91.

Rofiandaru, M. (2013). Sistem Pembelajaran Bahasa Isyarat (SIBI) Menggunakan Metode Komunikasi Total Untuk Penyandang Tunarungu Di SLBN Semarang. Tersedia: Http://Eprints. Dinus. Ac. Id/12344/1/Jurnal_12272. Pdf.

Setyawan, O. G. (2015). Pengaruh Penggunaan Media Teka-Teki Silang Bergambar Terhadap Penguasaan Kosakata Peserta Didik Tunarungu Kelas IV. Jurnal Ortopedagogia, 1(4), 289295.

Somantri, S. (2012). Psikologi anak luar biasa,(cetakan ke 4). Bandung: Refika Aditama.

Surjono, H. D. (2017). Multimedia pembelajaran interaktif: konsep dan pengembangan. Yogyakarta: UNY Press.

UUD. (1945). Undang-Undang Dasar Negara Republik Indonesia Tahun 1945. Sekretariat Jenderal MPR RI.

Wasita, A. (2012). Seluk-Beluk Tunarungu dan Tunawicara Serta Strategi Pembelajarannya. Jogjakarta: Javalitera.

Yuniati, Y. (2013). Pengembangan Perangkat Lunak Pembelajaran Bahasa Isyarat Bagi Penderita Tunarungu Wicara. Jurnal Generic, 6(1), 2932.

Zakia, D. L., Sunardi, S., \& Yamtinah, S. (2016). Pemilihan dan Penggunaan Media dalam Pembelajaran IPA Siswa Tunarungu Kelas XI Di Kabupaten Sukoharjo. Sainsmat: Jurnal Ilmiah Ilmu Pengetahuan Alam, 5(1). 